\title{
Effects of restoration management on the estuarine isopod Cyathura carinata: mediation by trematodes and habitat change
}

\author{
S. M. Ferreira - A. Brandão - A. Baeta - J. M. Neto $\cdot$ A. I. Lillebø • \\ K. T. Jensen · M. A. Pardal
}

Received: 11 July 2005 / Accepted: 11 August 2006/ Published online: 30 September 2006

(C) Springer-Verlag 2006

\begin{abstract}
A restoration programme was introduced in the Mondego Estuary (Portugal) to recover seagrass beds of Zostera noltii endangered by eutrophication. A long-term survey of 10 years was used to assess the development of the processes involved, focusing one of the key species (Cyathura carinata, Isopoda). The mitigation measures implemented since 1998 (nutrient loading reduction, freshwater circulation improvement and seagrass bed protection) enhanced water quality and seagrass recovery, thus preventing the development of macroalgal blooms. C. carinata was resilient to the occurrence of floods and macroalgal blooms, although both events caused dispersion of individuals. This isopod was not much influenced by the changes occurring in the estuary, showing an unalterable population structure during the entire study period. After 1998, its density and biomass became more stable at an inner unvegetated sand flat area, where this isopod was most abundant; its population slightly increased in a bare mud flat at the middle section of the estuary; but it could not establish successfully in a downstream
\end{abstract}

Communicated by S.A. Poulet, Roscoff.

S. M. Ferreira $(\bowtie) \cdot$ A. Brandão $\cdot$ A. Baeta

J. M. Neto - A. I. Lilleb $\emptyset$ - M. A. Pardal

IMAR - Institute of Marine Research,

Department of Zoology, University of Coimbra,

A/C Largo Marquês de Pombal,

3004-517 Coimbra, Portugal

e-mail: smff@ci.uc.pt

K. T. Jensen

Department of Marine Ecology,

Institute of Biological Sciences,

University of Aarhus, Finlandsgade 14,

DK-8200 Aarhus N, Denmark
Z. noltii bed, contrarily to other common estuarine species. Apart from other unknown reasons, the disrupted balanced between trematodes and their hosts, caused by the eutrophication processes, may have an important role in the discontinuity of $C$. carinata at the $Z$. noltii bed. If the intertidal areas become fully restored to the original seagrass coverage, high prevalence and intensity trematodes may prevent this isopod and other crustaceans from recovering within the intervened areas, by enhancing host mortality and recruitment failure. In order to avoid this kind of situation, it may be necessary to survey the levels of parasite infestation within the target hosts and safeguard areas where crustaceans present healthy populations.

\section{Introduction}

Coastal zones are recognised as some of the world's most productive ecosystems (Clark 1996), in which eutrophication is one of the major threats (Kennish 1997; Cloern 2001; Livingston 2001; Dolbeth et al. 2003). The processes triggered by excessive nutrient enrichment of coastal waters are complex, but usually cause shifts in primary producers and ultimately in the structure of food webs, lowering species richness, total biomass and secondary production (Hartog and Phillips 2000; Norkko et al. 2000; Livingston 2001; Dolbeth et al. 2003; Cardoso et al. 2005; Verdelhos et al. 2005). In fact, one of the most common signs of eutrophication is the decline of seagrass assemblages, due to proliferation of opportunistic algae (Valiela et al. 1997; Raffaelli et al. 1998; Cloern 2001). Nowadays, frameworks for tidal wetlands' restoration have 
been developed and the recovery of seagrass beds and of their associated faunal communities has been addressed (Jonge et al. 2000; Katwijk and Hermus 2000; Reise 2002).

The Mondego River (Fig. 1) forms a small temperate intertidal estuary (1,600 ha) located in the south of Europe. This coastal system supports several industries and receives an agricultural run-off from 15,000 ha of rice and cornfields cultivated in upstream areas. This well-documented estuary has shown increasing symptoms of eutrophication since the 1980s (Cardoso et al. 2005). Seasonal proliferations of green macroalgae Ulva sp. occurred along with a drastic reduction of Zostera noltii beds and impoverishment of macrobenthic communities (Dolbeth et al. 2003; Ferreira et al. 2004; Cardoso et al. 2005; Verdelhos et al. 2005). The implementation of a recovery programme was necessary to avoid the total loss of the $Z$. noltii beds and to improve their surrounding environment (Cardoso et al. 2005; Lillebø et al. 2005). Since 1998, several mitigation measures were introduced with the aim of protecting the existing beds, improving freshwater circulation and reducing nutrient loading into the south arm system. The Mondego Estuary has been monitored since the early 1990s for several national and international projects. Long-term studies are not very common in Ecology, but they are important to build up historical reference databases and ensure that

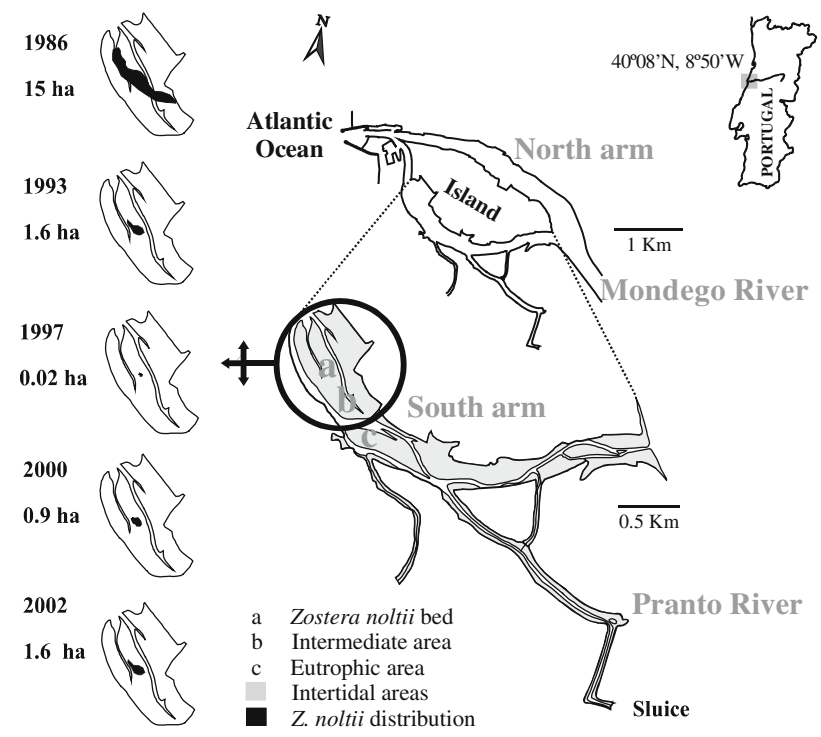

Fig. 1 Location of the Mondego Estuary. Indication of the sampling stations at the south arm and area of occupation of the Z. noltii beds from 1986 to 2002. Mapping was based on field observations, aerial photographs and GIS methodology (ArcView GIS 8.2) gathered evidence is logically integrated (Franklin 1989; Taylor 1989; Hobbs and Norton 1996), namely in the cases of rare and stochastic episodes or slow events with years of duration. So, the long-term data gathered by the IMAR-CIC research team can be used to assess the effectiveness of this restoration programme. The isopod Cyathura carinata is a keyspecies in the Mondego Estuary and has been the subject of a few studies, inclusively related to the eutrophication processes occurring in the system (Dolbeth et al. 2003; Ferreira et al. 2004). This invertebrate is a tube-dwelling ambush predator and also an important member of macrobenthic assemblages from many European estuaries, with a significant role in estuarine trophic webs (Amanieu 1969; Bamber 1985; Ólafsson and Persson 1986; Ferreira et al. 2004). C. carinata has the particularity of being a protogynous hermaphrodite, in which females may sex reverse into males. This isopod is also a second intermediate host to microphallid trematodes (Jensen et al. 2004) and these parasites have an important role on its population dynamics (Ferreira et al. 2005). Therefore, one of the main objectives of the present work is to compare some characteristics of C. carinata's population dynamics (e.g. density, biomass, population structure, growth and secondary production), before and after estuarine management, in order to assess if it can be influenced by the mitigation measures applied in the Mondego Estuary. It is also intended to evaluate the influence of episodic events (e.g. algal blooms, floods and possible mass mortality induced by parasites) in slow ecological processes (i.e. population dynamics of $C$. carinata) over a period of 10 years, in order to provide some recommendation guidelines for ecosystems restoration and coastal management.

\section{Materials and methods}

Study site

The Mondego Estuary is located in the central western coast of Portugal (Fig. 1). A small island divides it into two arms with different hydrological characteristics. The north arm is a navigation channel frequently dredged (4-8 $\mathrm{m}$ deep at high tide, with a tidal range of $1-3 \mathrm{~m})$. The south arm is shallow (2-4 m deep at high tide) and has extensive intertidal areas. Before 1998, this arm was silted-up in the upstream sections, which obstructed the Mondego River outflow. So, water circulation in this system depended mostly on tides and on a small freshwater 
input from the tributary Pranto River. The flow of this river was in turn controlled by a sluice that was opened according to the water needs of upstream rice fields. After 1998, this sluice was closed to lower nutrient loading into the south arm. Pranto freshwater is now discharged by another sluice located further upstream in the Mondego River and the connection between the two arms was enlarged, in order to improve the hydraulic regime in the southern system of the estuary.

More than three decades ago, $Z$. noltii beds covered most of the south arm intertidal areas. In 1986, they were reduced to 15 ha (Fig. 1). In 1993, three sampling stations were established along a spatial gradient of different eutrophication symptoms (Fig. 1), based in the shift of primary producers: (a) a $Z$. noltii bed located in downstream mud flats, which represents a noneutrophic situation, more or less corresponding to the original state of the system; (b) an intermediate area located in the middle section, a mud flat which was covered by $Z$. noltii until 1993, but not afterwards; and (c) a eutrophic area, which is a sand flat in the inner parts of the estuary, from where Z. noltii disappeared more than 25 years ago and where seasonal green macroalgal blooms (Ulva sp.) frequently occurred before the restoration measures.

\section{Field programme}

Monthly sampling was performed from January 1993 to December 2002. To facilitate seagrass recovery, no samples were collected between September 1995 and December 1998 at the intermediate area and Z. noltii bed, whereas at the eutrophic area the sampling interruption started later in January 1997. Samples consisted of 6-10 random cores $(13.5 \mathrm{~cm}$ diameter) taken to a depth of $15 \mathrm{~cm}$ in the three studied areas. Each core was washed on a $0.5 \mathrm{~mm}$ mesh sieve and the remaining material was preserved in $4 \%$ buffered formalin. On all occasions, salinity was measured in situ. Likewise, water samples were analysed for dissolved inorganic nitrogen (DIN) and dissolved inorganic phosphorus (DIP), according to standard methods (Strickland and Parsons 1972; Limnologisk Metodik 1992), the results of which had been already published by Lillebø et al. (2005). The nearby Coimbra forecast station of the Portuguese Institute of Meteorology provided the monthly precipitation and atmospheric temperature data.

\section{Seagrass, macroalgae and Cyathura carinata}

All animals and plants were sorted in the laboratory. The animals were kept in $70 \%$ ethanol. Green mac- roalgae and $Z$. noltii (leaves and rhizomes) were dried for $48 \mathrm{~h}$ at $60^{\circ} \mathrm{C}$ and their ash free dry weight (AFDW) was determined by loss on ignition $\left(8 \mathrm{~h}\right.$ at $\left.450^{\circ} \mathrm{C}\right) . C$. carinata specimens were counted, sexed and measured for cephalic length. Total body length $(\mathrm{mm})$ and biomass (g AFDW) were determined with regression models already used by Ferreira et al. (2004): total body length $=0.745133+9.01010 \times$ cephalic length, $r^{2}=0.97, n=115$ and biomass $=0.0190549 \times$ cephalic length ${ }^{2.71815}, r^{2}=0.96, n=800$. All specimens were also inspected for the presence of microphallid trematode cysts inside their abdomen, which were removed and counted (Jensen et al. 2004).

\section{Data analyses}

The results were calculated as mean $\pm \mathrm{SE}$ of all the random cores taken every month, in each sampling station. Still, these results were presented as moving averages to visually simplify the long data series (except for the population structure, growth and secondary production). Statistical analyses were done employing the MINITAB 10.2 and SigmaStat 2.0 softwares, using the mean results of each monthly sample as replicates to compare the periods before and after estuarine management. If required assumptions were invalidated, proper transformations or nonpararametric tests were performed.

Cyathura carinata population structure was defined by tracking recognisable cohorts in size-frequency distributions from successive dates, using ANAMOD software. Isopods infected by trematodes were disregarded. Field growth rates were expressed by the equation of Gaschütz et al. (1980), $L_{t}=L_{\infty}$ $\left(1-\mathrm{e}^{-[K D(t-t \mathrm{o})+C(K D / 2 \pi) \sin 2 \pi(t-t \mathrm{~s})]}\right) 1 / D$, where $L_{t}$ is the length of the organism at a given time $t ; L_{\infty}$ the maximum possible length of the organism; $t_{0}$ the instant when the organism would have a length equal to zero; $t_{\mathrm{s}}$ the time interval between the start of growth (when $t=0$ ) and the first growth oscillation, being growth expressed by a sine curve with a 1-year period; $K$ the growth constant; $C$ the parameter in which the values can range from 0 to 1 , depending on the species; and $D$ the parameter that expresses metabolic deviations from the von Bertalanffy's $2 / 3$ rule.

Secondary production was based on the increment summation method. The values of growth production $(P)$ were expressed as follows: $P=\sum_{n=1}^{N} P_{\mathrm{cn}}$, where $P_{\mathrm{cn}}$ is the growth production of a cohort $n$. The mean population biomass $\bar{B}$ was calculated as follows: $\bar{B}=(1 / T) \sum_{n=1}^{N} \bar{B}_{n} t$, where $T$ is the period of study; $N$ 
the number of cohorts in the period $T ; \bar{B}_{n}$ the mean biomass of the cohort $n$ and $t$ the duration of that same cohort.

\section{Results}

\section{Environmental characteristics}

The annual patterns of temperature and precipitation varied according to the warm temperate climate of the Mondego region. The winters of 1993-1994, 1995-1996 and 2000-2001 presented higher rainfall than the others (Fig. 2a). During those periods, an extensive opening of the Pranto River sluice caused strong salinity declines (Fig. 2b), sometimes to values lower than 5. After the introduction of management measures, there was an effective reduction of DIN concentrations (essentially in the form of ammonia) in the south arm of the Mondego estuary, but the DIP concentrations did not show significant differences (see Lillebø et al. 2005). Between 1993 and 1997, the $Z$. noltii bed suffered an area reduction from 1.6 to 0.02 ha (Fig. 1), as well as a decline of the seagrass biomass (Fig. 3a) from 253 to $5 \mathrm{~g} \mathrm{~m}^{-2}$ AFDW. The
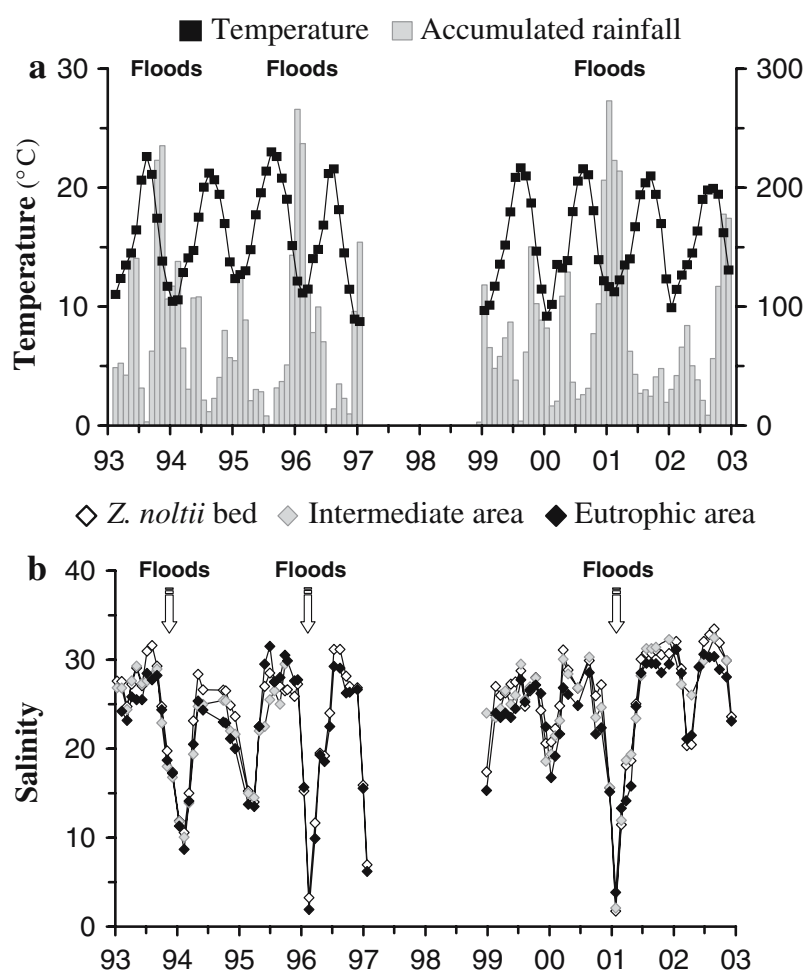

Fig. 2 Variation of a air temperature and precipitation at the Mondego Estuary region and $\mathbf{b}$ water salinity at the south arm of the Mondego Estuary, from January 1993 to December 2002
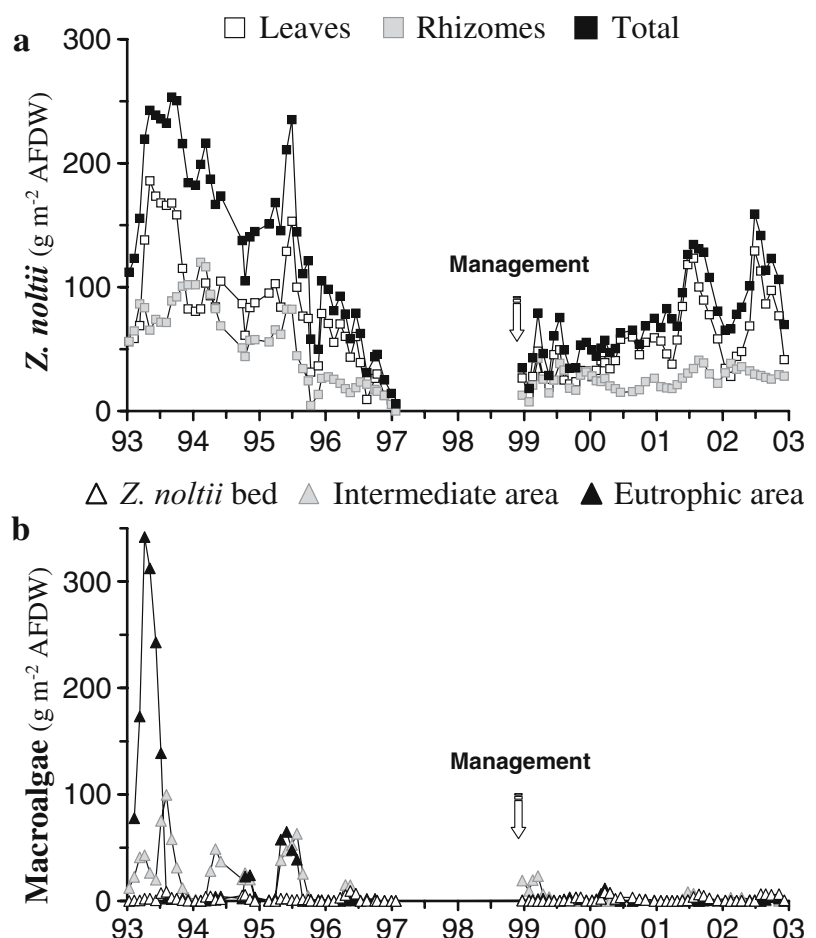

Fig. 3 Variation of a seagrass leaves, rhizomes and total biomass at the $Z$. noltii bed and $\mathbf{b}$ green macroalgal biomass at the three sampling stations of the Mondego Estuary, from January 1993 to December 2002

scenario changed when management measures were implemented, with a recovery of the seagrass biomass (maximum of $159 \mathrm{~g} \mathrm{~m}^{-2}$ AFDW, Wilcoxon test: $W=2,689, P<0.001$ ) and area of occupation (up to 1.6 ha in 2002). Green macroalgae (Fig. 3b) were scarce at the $Z$. noltii bed $\left(1.90 \pm 0.26 \mathrm{~g} \mathrm{~m}^{-2}\right.$ AFDW, mean \pm SE), both before and after management. In the intermediate and eutrophic areas, algal blooms were frequent before $1998(19.80 \pm 3.60$ and $35.10 \pm$ $12.00 \mathrm{~g} \mathrm{~m}^{-2}$ AFDW, mean $\pm \mathrm{SE}$, respectively), but afterwards they ceased to occur (Wilcoxon tests: $W=2$ 573 for the intermediate area, $W=2,416$ for the eutrophic area, $P<0.001$ ).

\section{Cyathura carinata}

The $C$. carinata population exhibited a characteristic annual pattern of variation. Density (Fig. 4a) increased during summer, achieving maximum values in autumn/ winter and then declined until late spring. $C$. carinata's density was higher at the eutrophic area than at the other sampling sites and showed no significant differences before and after 1998 (Table 1). Still, the maximum densities achieved in the rainy autumn/winter months of 1993-1994 (which was also preceded by a 


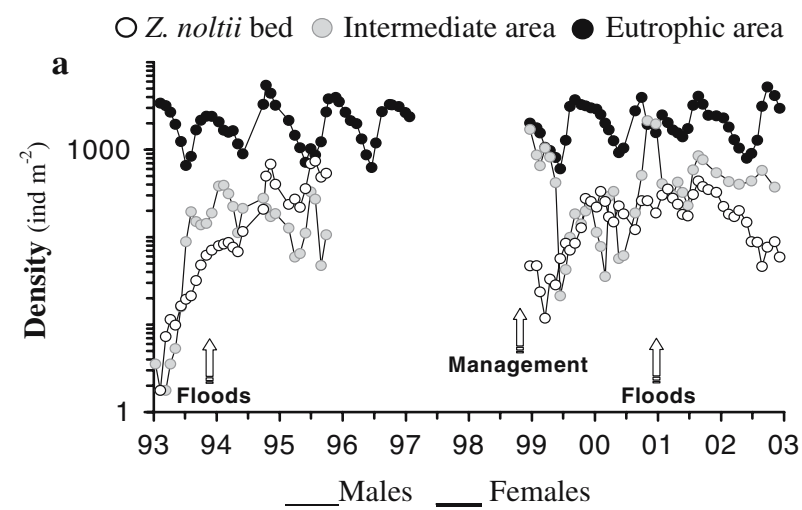

dance showed wide fluctuations at the intermediate area (Fig. 4a). There were only few isopods in this site prior to 1998 , but afterwards they became comparatively more abundant (Table 1 ), reaching two peaks of nearly 2,000 ind. $\mathrm{m}^{-2}$ in January of 1999 and again in the end of 2000. At the beginning of 1993, C. carinata was absent from the $Z$. noltii bed (Fig. 4a); however, its population sprouted until the end of 1995 , reaching 1,000 ind. $\mathrm{m}^{-2}$. After 1998, the population recovered from a non-existing situation, similar to the one of 1993-1995 (Table 1). There were approximately 550 isopods per $\mathrm{m}^{2}$ from autumn 1999 until spring of 2002. Then, the population started to decline, being on the verge of disappearing from this site by the end of 2002 .

It was possible to recognise and follow 12 cohorts along the 10 years of sampling (Fig. 4b) and no differences in the population structure were evident before and after 1998. Each cohort was estimated to last 23-24 months. Every year, two cohorts coexisted. A new cohort urged at the end of spring, while the oldest one ( 2 years old) disappeared at the same time. So, the population recruited once per year, for an extended period of time, producing a single annual cohort. The 1-year-old cohorts were also able to reproduce, with males differentiating from females at the 8th month of life (by direct development). Like the 2-year-old males (which resulted from sex reversal of females-protogynous hermaphroditism), they showed higher mean cephalic lengths than females and disappeared after reproduction. When a cohort recruited, the newborn isopods accounted for $80-90 \%$ of the population. At the time that they reproduced for the first time, these 1-year-old isopods suffered an abrupt decline and became to represent only $10-20 \%$ of the population until the end of their life span. Growth was continuous peaks became similar after 1998 . C. carinata's abun-

spring algal bloom) and 2000-2001 were significantly lower than the corresponding ones of 1994-1995 (oneway ANOVA: $\left.F_{7,35}=2.96, P<0.05\right)$. These annual

Table 1 Comparison of $C$. carinata population dynamics characteristics (mean \pm SE) before and after estuarine management in the south arm of the Mondego Estuary, with the results of the statistical analyses performed (Wilcoxon tests)

\begin{tabular}{|c|c|c|c|c|c|c|}
\hline & \multicolumn{2}{|c|}{ Zostera noltii bed } & \multicolumn{2}{|c|}{ Intermediate area } & \multicolumn{2}{|c|}{ Eutrophic area } \\
\hline & Before 1998 & After 1998 & Before 1998 & After 1998 & Before 1998 & After 1998 \\
\hline Density (ind. $\mathrm{m}^{-2}$ ) & $\begin{array}{l}210 \pm 43 \\
W=102\end{array}$ & $\begin{array}{l}179 \pm 16 \\
>0.05\end{array}$ & $\begin{array}{r}156 \pm 21 \\
W=68\end{array}$ & $\begin{aligned} & 500 \pm 69 \\
< & 0.001\end{aligned}$ & $\begin{array}{r}2,038 \pm 215 \\
W=1,0\end{array}$ & $\begin{array}{l}2,152 \pm 158 \\
>0.05\end{array}$ \\
\hline Biomass $\left(\mathrm{g} \mathrm{m}^{-2}\right)$ & $\begin{array}{r}0.81 \pm 0.16 \\
W=98\end{array}$ & $\begin{array}{l}1.08 \pm 0.12 \\
>0.05\end{array}$ & \multicolumn{2}{|c|}{$W=2,158, P<0.001$} & \multicolumn{2}{|c|}{$W=1,985, P>0.05$} \\
\hline Population structure & \multicolumn{2}{|c|}{-} & \multicolumn{2}{|c|}{-} & \multicolumn{2}{|c|}{ No changes } \\
\hline $\begin{array}{l}\text { Growth (constant K in } \\
\text { Gaschütz et al. 1980) }\end{array}$ & \multicolumn{2}{|c|}{-} & \multicolumn{2}{|c|}{-} & Higher K & Lower K \\
\hline $\begin{array}{l}\text { Trematodes' prevalence } \\
(\%)\end{array}$ & $\begin{array}{r}31.8 \pm 4.2 \\
W=1,0\end{array}$ & $\begin{array}{l}35.6 \pm 4.2 \\
>0.05\end{array}$ & $\begin{array}{r}20.7 \pm 4.7 \\
W=82\end{array}$ & $\begin{aligned} & 33.7 \pm 4.0 \\
< & 0.05\end{aligned}$ & $\begin{array}{r}6.7 \pm 1.2 \\
W=96\end{array}$ & $\begin{array}{l}6.6 \pm 0.9 \\
>0.05\end{array}$ \\
\hline $\begin{array}{l}\text { Trematode's intensity } \\
\quad\left(\text { cysts host }^{-1}\right)\end{array}$ & \multicolumn{2}{|c|}{$W=995, P>0.05$} & \multicolumn{2}{|c|}{$W=841, P<0.05$} & $\begin{array}{r}1.28 \pm 0.89 \\
W=1,0\end{array}$ & $\begin{array}{l}1.34 \pm 0.11 \\
P>0.05\end{array}$ \\
\hline $\begin{array}{l}\text { Growth production } \\
\left(\mathrm{g} \mathrm{m}^{-2} \text { year }^{-1}\right)\end{array}$ & \multicolumn{2}{|c|}{-} & \multicolumn{2}{|c|}{-} & \multicolumn{2}{|c|}{$W=20, P>0.05$} \\
\hline
\end{tabular}



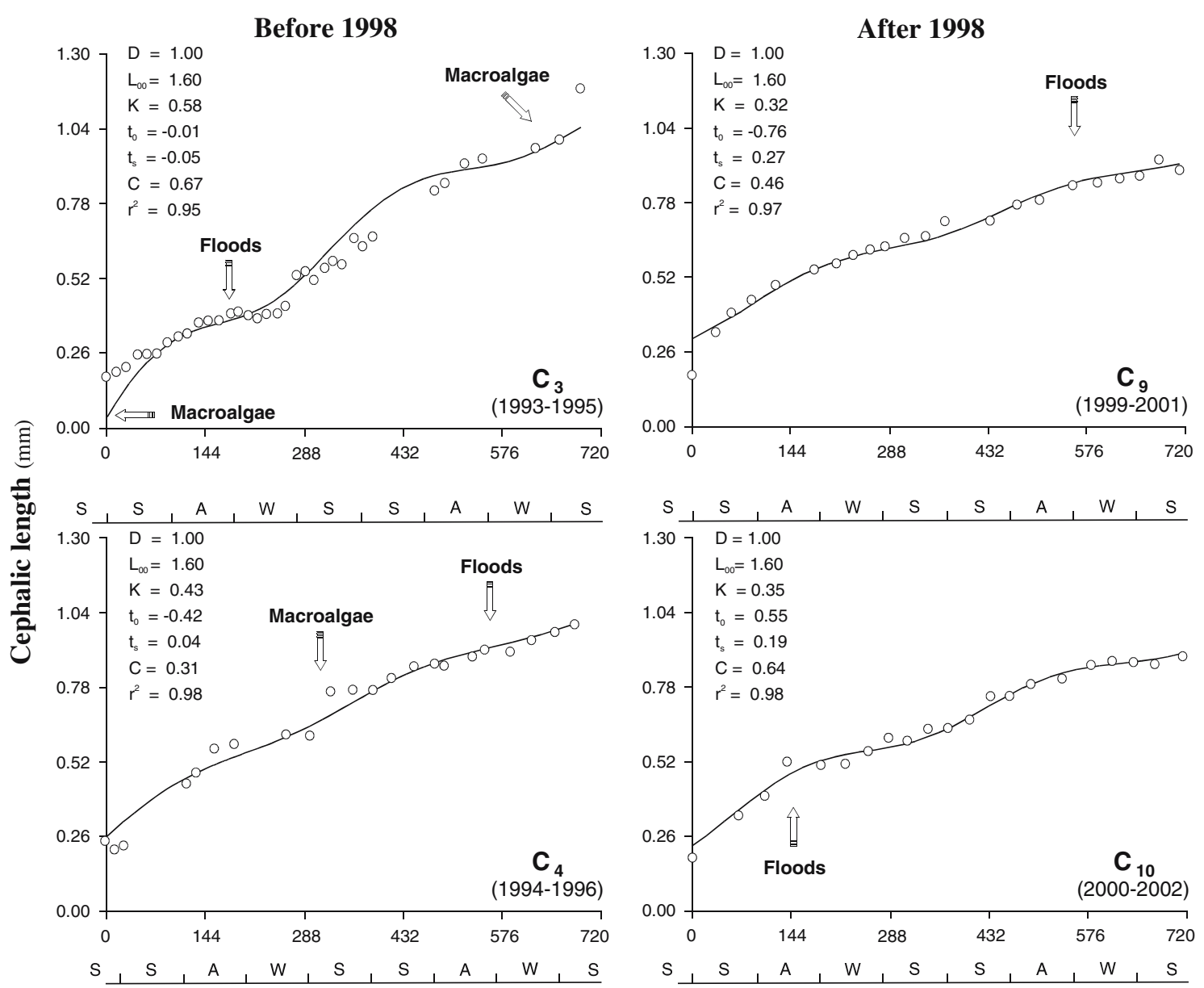

Time (days \& seasons)

Fig. 5 Cyathura carinata growth models (Gaschütz et al. 1980), calibrated with field growth data of females from cohorts $\mathrm{C}_{3}, \mathrm{C}_{4}, \mathrm{C}_{9}$ and $\mathrm{C}_{10}$, with indication of the respective parameters. Males were disregarded, as there were few observations

throughout the isopods' entire life, varying with age, sex and seasonality, being higher in the early life stages, in males and during spring and summer (Figs. 4b, 5). The growth constants $(K)$ of females from cohorts $\mathrm{C}_{3}$ and $\mathrm{C}_{4}$ were higher than those from $\mathrm{C}_{9}$ and $\mathrm{C}_{10}$ (Fig. 5). The cohorts prior to 1998 reflected seasonality more markedly than those subsequent to the restoration programme, growing slightly larger during the reproduction seasons.

Less isopods were infected with microphallid trematodes in the eutrophic area than in the other sites (Fig. 6a, Kruskal-Wallis: $H=36.8, P<0.001$ ), and the mean number of microphallid cysts per infected host was lower as well (Fig. 6b, Kruskal-Wallis: $H=11.7$, $P<0.01)$. Throughout the entire study period, both prevalence and mean intensity of microphallids followed the same annual pattern as the isopods' density, at all sampling stations (although no significant correlations were found). In the $Z$. noltii bed, microphallid infections increased gradually along with $C$. carinata density. When prevalence approached $100 \%$, like in the summers of 1999 and 2002, density declined and the population crashed afterwards, as might have happened before 1993 and after 1995. In those periods, the mean intensity of trematodes increased as well, reaching approximately ten cysts per infected host. Prevalence and intensity of microphallid trematodes followed a similar pattern at the intermediate area, although in a more erratic manner and not so drastically. This site was the only one showing an increase of the parasitic pressure after 1998 (Table 1).

Growth production ( $P$, Table 2$)$ showed a seasonal tendency to be lower in spring and higher in autumn. It seemed to be higher in periods when green macroalgae developed and lower when precipitation was more abundant. Production estimates from the seasons following both types of phenomena were also negatively affected. The lower annual estimates were obtained in 
Z. noltii bed $\bigcirc$ Intermediate area Eutrophic area
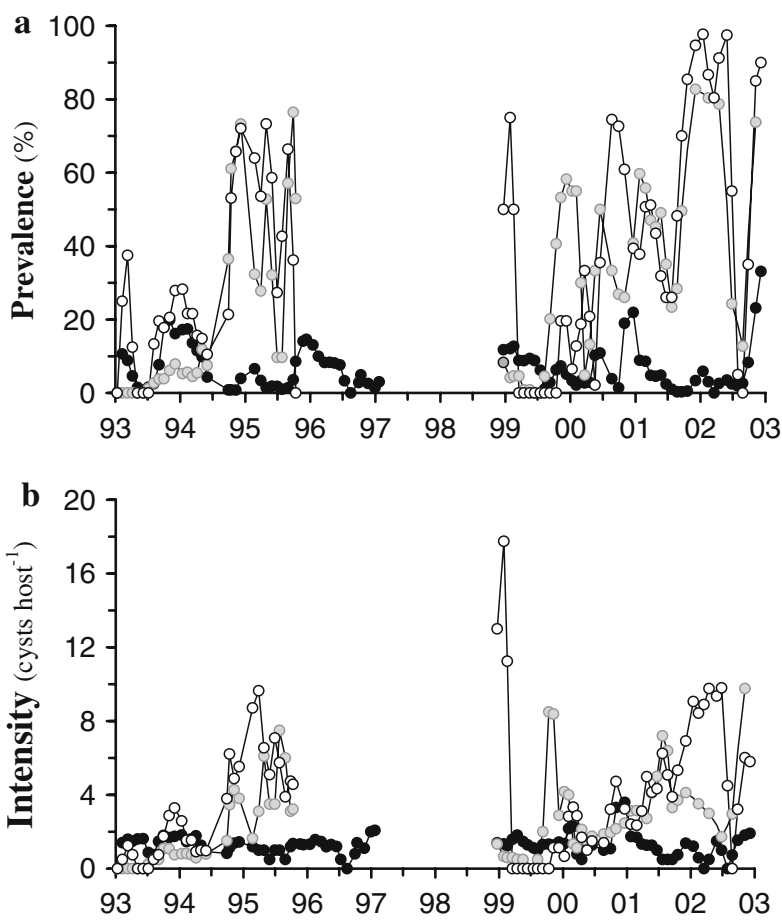

Fig. 6 Variation of a the proportion of isopods infected with microphallid trematodes (prevalence) and $\mathbf{b}$ the mean number of microphallid cysts per infected isopod host (mean intensity), at the three sampling stations of the Mondego Estuary, from January 1993 to December 2002

1995, 2000 and 2001, when lower secondary productions occurred in rainy autumns and/or in winters, and also in seasons subsequent to algal growth. The annual estimate from 1993 was balanced between an extraor- dinary high growth production during the major spring algal bloom and a low production in the rainy fall. The highest annual value was in 1994, when secondary production increased during a small autumn algal growth. The mean population biomass $(\bar{B}$, Table 2$)$ was usually higher in autumn and winter. It followed the same tendency as growth production, regarding the occurrence of algal development and intensive rainfall. Annual $P / \bar{B}$ ratios tended to decrease until 1998 and increase afterwards, being the highest estimates obtained in spring and summer.

\section{Discussion}

The mitigation measures implemented in 1998 are improving water quality in the south arm of the Mondego Estuary. The enlargement of the connection between the two arms reduced the residence time of water in the estuary (from 5-7 days to 1 day) and favoured nutrient dilution, thus improving freshwater circulation (Lillebø et al. 2005; Verdelhos et al. 2005). Additionally, a rational management of fertilizer usage and sluice discharge reduced the input of nutrients (Lilleb $\varnothing$ et al. 2005), which all together prevent favourable conditions for the development of macroalgal blooms. Therefore, it seems that eutrophication stressors are abating and that conditions have been established for seagrass recovery. In fact, the $Z$. noltii has been recovering, both in terms of biomass and area of occupation. Nevertheless, more management measures may be required to restore the south arm to its

Table 2 Growth production, mean population biomass and $P / \bar{B}$ ratio of $C$. carinata at the eutrophic area, estimated annual and seasonally, from January 1993 to December 2002

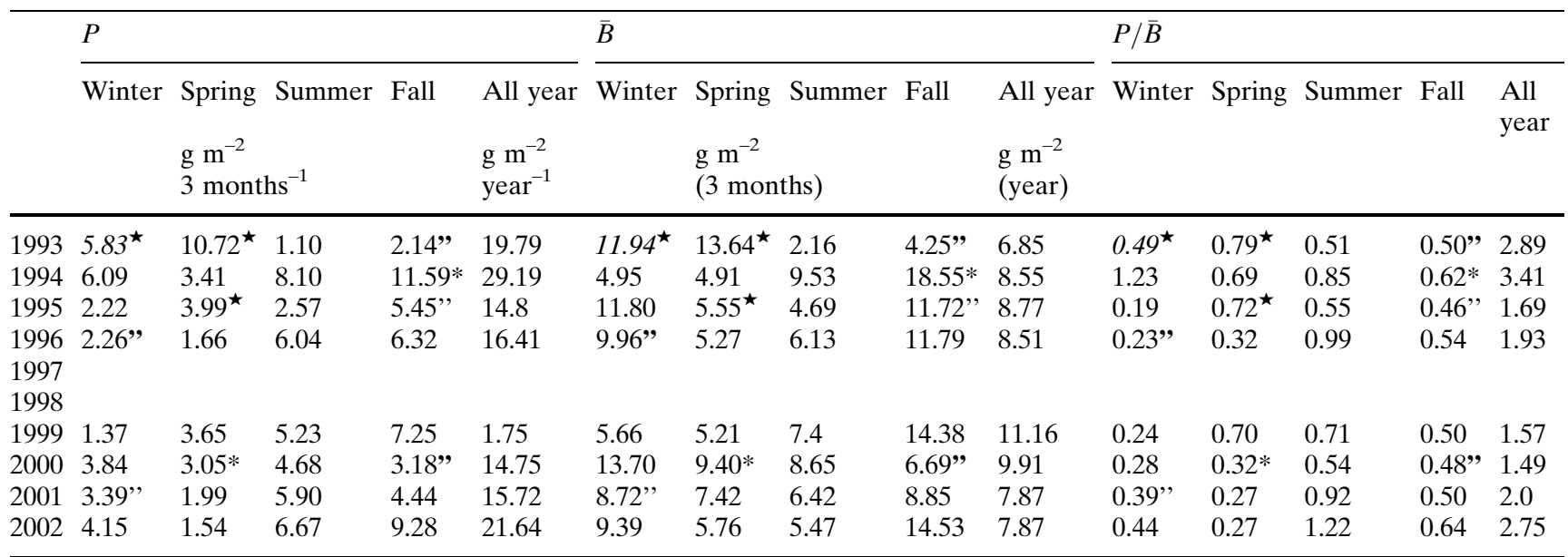

Size-frequency polymodal analysis was not possible to be performed for the other two sampling stations, thus secondary production could not be assessed. The symbol (*) indicates the periods when green macroalgae occurred and (") refers to the ones when rainfall was more abundant. The bigger the symbol, the higher the intensity of the phenomena. The winter of 1993 (values in italics) corresponds only from the period between February and March 
original state, such as using coastal engineering and seagrass transplants (Cardoso et al. 2005). Facing this scenario, what consequences may it have for $C$. carinata or other similar macroinvertebrates?

Cyathura carinata was not much influenced by the mitigation measures implemented in the estuary, especially as regards its population structure (Table 1). Cyathura are known euryokous species, occurring in different salinities (Burbanck and Burbanck 1979), tidal ranges and biotopes, from pebble-dominated sediments (Bamber 1985) to rooted-macrophyte beds (Amanieu 1969; Ólafsson and Persson 1986; Ferreira et al. 2004). Therefore, $C$. carinata is probably not the most suitable bioindicator of ecosystems health; however, this isopod is a key species in many European estuaries (Amanieu 1969; Bamber 1985; Ólafsson and Persson 1986), for which it is necessary to assess and predict its responses to habitat changes.

In the pre-restoration period, $C$. carinata's individuals grew larger during the reproduction seasons. Thus, they theoretically could produce more offspring, as the number of embryos in a brood pouch is related with the size of the female (Ferreira et al. 2005). These higher growth rates may have resulted from a compensation for the occurrence of multiple algal blooms and floods, which have disrupted the normal development of the population. Moreover, the isopods temporally benefited from the increasing habitat complexity, food resources and protection against predators, provided by the spring algal blooms, which was reflected in the seasonal growth productions and mean population biomass (Raffaelli et al. 1998; Norkko et al. 2000; Hemmi and Jormalainen 2002). Nevertheless, algae affected negatively the recruitment of juveniles, promoting dispersion to adjacent areas and/or differential mortality (Ferreira et al. 2004). On the other hand, floods and consequent extensive sluice openings were responsible for abrupt salinity declines and stronger water currents. These events had negative repercussions for $C$. carinata (e.g. density, growth production and mean population biomass), once that the unvegetated sand flat offers little protection against erosion, compared to the $Z$. noltii bed or even the intermediate area (where some seagrass rhizomes still can be found). From the lowest annual abundance peak observed at the eutrophic area in 1993, it was possible to infer a synergistic action from the autumn floods and the harmful spring macroalgal blooms. Nonetheless, C. carinata was resilient to these disturbances, being able to recover in the following years.

Cyathura carinata's population remained abundant and well age-structured at the eutrophic area through the entire study period. This feature was antagonistic to other key species, such as the mud snail Hydrobia ulvae or the bivalve Scrobicularia plana (Cardoso et al. 2005; Verdelhos et al. 2005). The annual density peaks became similar after 1998, showing a slight tendency to increase. C. carinata contributed to a considerable fraction $(25-61 \%)$ of the annual secondary macrobenthic production in this site, where the eutrophication processes led to a progressive impoverishment of the benthic fauna (Dolbeth et al. 2003). Consequently, any stress factor to its population may contribute to destabilise even more an already disturbed macrobenthic assemblage.

Cyathura carinata's abundance usually increased after summer in all the sampling sites, when reproduction had ended, mostly due to juvenile dispersion from upstream sections of the estuary. Still, its density became less abundant towards the $Z$. noltii bed. After the introduction of the restoration programme, the density and biomass of this isopod increased at the intermediate area (Table 1), although it occurred in an unstable manner. Despite the signs of population recuperation, this sampling site was the most disturbed by direct human activity, where the sediment was constantly revolved by fishermen searching for bait (e.g. Hediste diversicolor) and bivalves (e.g. Cerastoderma edule), being unfavourable for the settlement of macrobenthic invertebrates. $C$. carinata was scarce at the $Z$. noltii bed during the entire study period, in spite of the fact that this is the richest habitat, in terms of biodiversity and biomass, within the intertidal areas of the Mondego and other international estuaries (Duarte 2002; Dolbeth et al. 2003; Heck et al. 2003). This isopod showed some signs of recovery in this site, just to collapse afterwards, both before and after management (Table 1). Contrarily to other key macrobenthic species of the Mondego Estuary (e.g. H. ulvae or S. plana), which have prospered in all the sampling sites (Cardoso et al. 2005; Verdelhos et al. 2005), C. carinata was not able to establish successfully in the Z $Z$. noltii bed. Many unknown reasons may be invoked to explain how or why $C$. carinata immigrants are unable to settle in this area, such as specific habitat selection. For instance, both macroalgae and seagrasses constitute a physical barrier that might interfere with ambush-like predatory feeding mechanisms of this isopod. Still, C. carinata has been observed in Z. noltii and other rooted-macrophyte beds (Amanieu 1969; Ólafsson and Persson 1986; Blanchet et al. 2005). The high prevalence and intensity of microphallid trematodes may have an important role in the temporal fluctuations of the hosts' abundance (Jensen et al. 2004). The influence of these parasites in C. carinata was previously assessed to induce lower survivorship, growth 
rates and reproduction failure (Ferreira et al. 2005). The high infection levels observed at the $Z$. noltii bed and at the intermediate area, in 1995, in the beginning of 1999 and in 2002 were twice those used experimentally (Ferreira et al. 2005). Microphallids encyst within $C$. carinata (second intermediate host), but are transmitted by mud snails $H$. ulvae (first intermediate host), which in turn become infected by ingesting microphallid eggs released in water birds' faeces (final hosts). The low occurrence of parasites at the eutrophic area may be due to the fact that there are no adult mud snails in this site (Cardoso et al. 2005), which cannot be parasitised by microphallids and therefore transmit them to the isopods. On the other hand, juvenile $C$. carinata that disperse to the $Z$. noltii bed and also to the intermediate area have a high probability of getting infected by these parasites, as H. ulvae is a dominant species. This mud snail is represented by all age classes at the $Z$. noltii bed and can reach densities up to 300,000 ind. $\mathrm{m}^{-2}$ (Cardoso et al. 2005). Even low prevalences $(<5 \%$, S.M. Ferreira, personal observation) represent several thousands of infected $H$. ulvae per $\mathrm{m}^{2}$, which will transmit microphallids to the incoming juvenile isopods, enhancing their mortality and causing recruitment failure. No differences regarding microphallids' prevalence and intensity were established between the periods prior and subsequent to estuarine management in the extreme sampling sites (Table 1). At the intermediate area, some increase in the prevalence and intensity of trematodes after 1998 (Table 1) was noticed, which may have resulted from the combination of dimly increased abundance of $C$. carinata in a site very close to the $Z$. noltii bed in frank recovery, where H. ulvae is a flourishing population. So, as digenetic trematodes interfere with the population dynamics of $C$. carinata, they are a liability for the success of this isopod, once that (a) it is a species with direct development, (b) reproduces only once per year, (c) only $10-20 \%$ of the 1-year-old individuals are able to survive and achieve the 2 years of estimated life span and (d) males are a minority in the population (if infected, males may be unable to compete for females or mate with them) (Ferreira et al. 2004, 2005).

Tidal wetland restoration programmes require a full understanding of the interactions between all populations and multiple stressors, in order to become successful. Management changes in ecosystems may create unexpected animal responses to habitat modifications, such as parasite-host interactions. The mitigation measures introduced in the Mondego Estuary have been contributing for the recovery of the $Z$. noltii coverage and of its associated macrobenthic fauna. If the intertidal areas of the south arm of the Mondego
Estuary are restored to its original seagrass coverage, it can be expected that the inherent populations may prosper as well, including the opportunistic mud snail H. ulvae. If this gastropod becomes particularly abundant and dominant, then microphallid trematodes are foreseen to proliferate as well. High prevalence and intensity of these parasites may prevent not only $C$. carinata, but also other crustaceans that they use as their second intermediate hosts, from recovering within the intervened areas, by limiting the efficient population size or even by causing population fragmentation. In order to avoid this kind of situation, it may be necessary to: (a) survey the levels of parasite infestation within the target host populations; (b) promote the dispersion of $H$. ulvae individuals as long as the crustacean populations recuperate, not only within the growing area of $Z$. noltii coverage, but also by ensuring their distribution to other alternative habitats within the estuary, such as Scirpus maritimus and Spartina maritima saltmarshes; and (c) safeguard the areas where the crustacean populations are healthy. The increasing hazards that threaten coastal environments, mostly derived from anthropogenic impacts, may disrupt and interfere with the natural balance between parasites and their hosts, such as it seems to occur between trematodes, H. ulvae, C. carinata and the eutrophication processes involved in the Mondego Estuary. In this scenario, the knowledge acquired about the role of parasites becomes a significant issue for the management of life processes in coastal systems, which is often disregarded. The present work appeals to the recognition of the importance of parasites for understanding the dynamics and distribution of populations from shallow water ecosystems.

Acknowledgments This paper was supported by the FCT (Portuguese Foundation for Science and Technology) through a grant conceded to S.M. Ferreira (SFRH/BD/5392/2001). The authors are also grateful to all colleagues from IMAR-Coimbra for their collaboration and to the anonymous reviewers that contributed to improve this work.

\section{References}

Amanieu M (1969) Variations saisonnières de la taille et cycle reproducteur à Arcachon de Cyathura carinata (Krøyer). J Exp Mar Biol Ecol 4:79-89

Bamber RN (1985) The autoecology of Cyathura carinata (Crustacea: Isopoda) in a cooling water discharge lagoon. J Mar Biol Assoc UK 65:181-194

Blanchet H, Mountaudouin X, Chardy P, Bachelet G (2005) Structuring factors and recent changes in subtidal macrozoobenthic communities of a coastal lagoon, Arcachon Bay (France). Estuar Coast Shelf Sci 64(4):561-576

Burbanck WD, Burbanck MP (1979) Cyathura (Arthropoda: Crustacea: Isopoda: Anthuridae). In: Hart CW Jr, Fuller 
SLH (eds) Pollution ecology of estuarine invertebrates. Academic, New York, pp 293-323

Cardoso PG, Brandão A, Pardal MA, Raffaelli D, Marques JC (2005) The resilience of Hydrobia ulvae populations to anthropogenic and natural disturbances. Mar Ecol Prog Ser 289:191-199

Clark JR (1996) Coastal zone management handbook. CRC Press LLC, Boca Raton

Cloern JE (2001) Our evolving conceptual model of the coastal eutrophication problem. Mar Ecol Prog Ser 210:223-253

Dolbeth M, Pardal MA, Lilleb $\varnothing$ AI, Azeiteiro U, Marques JC (2003) Short- and long-term effects of eutrophication on the secondary production of an intertidal macrobenthic community. Mar Biol 143:1229-1238

Duarte CM (2002) The future of seagrass meadows. Environ Conserv 29:192-206

Ferreira SM, Pardal MA, Lillebø AI, Cardoso PG, Marques JC (2004) Population dynamics of Cyathura carinata (Isopoda) in a eutrophic temperate estuary. Estuar Coast Shelf Sci 61:669-677

Ferreira SM, Jensen KT, Martins PA, Sousa SF, Marques JC, Pardal MA (2005) Impact of microphallid trematodes on the survivorship, growth and reproduction of an isopod (Cyathura carinata). J Exp Mar Biol Ecol 318:191-199

Franklin JF (1989) Importance and justification of long-term studies in Ecology. In: Likens GE (ed) Long-term studies in ecology. Approaches and alternatives. Springer Berlin Heidelberg New York, pp 3-19

Gaschütz G, Pauly D, David N (1980) A versatile basic program for fitting weight and seasonally oscillating length growth data. ICES CM G24:1-23

Hartog C, Phillips RC (2000) Seagrasses and benthic fauna of sediment shores. In: Reise K (ed) Ecological comparisons of sedimentary shores. Springer, Berlin Heidelberg New York, pp 195-212

Heck KL, Hays G, Orth RJ (2003) Critical evaluation of the nursery role hypothesis for seagrass meadows. Mar Ecol Prog Ser 253:123-136

Hemmi A, Jormalainen V (2002) Nutrient enhancement increases performance of a marine herbivore via quality of its food alga. Ecology 83(4):1052-1064

Hobbs RJ, Norton DA (1996) Towards a conceptual framework for restoration ecology. Restor Ecol 4:93-110

Jensen KT, Ferreira SM, Pardal MA (2004) Trematodes in a Cyathura carinata population from a temperate intertidal estuary: infection patterns and impact on host. J Mar Biol Assoc UK 84:1151-1158
Jonge VN de, Jong DJ de, Katwijk MM (2000) Policy plans and management measures to restore eelgrass (Zostera marina L.) in the Dutch Wadden Sea. Helgol Mar Res 54:151-158

Katwijk MM, Hermus DR (2000) Effects of water dynamics on Zostera marina: transplantation experiments in the intertidal Dutch Wadden Sea. Mar Ecol Prog Ser 208:107-118

Kennish MJ (1997) Practical handbook of estuarine and marine pollution. CRC Press, Boca Raton

Lilleb $\varnothing$ AI, Neto JM, Martins I, Verdelhos T, Leston S, Cardoso PG, Ferreira SM, Marques JC, Pardal MA (2005) Management of a shallow temperate estuary to control eutrophication: the effect of hydrodynamics on the system's nutrient loading. Estuar Coast Shelf Sci 65:697-707

Limnologisk Metodik (1992) Ferskvandsbiologisk Laboratorium. Københavns Universitet (eds) Akademisk Forlag, København

Livingston RJ (2001) Eutrophication processes in coastal systems. CRC Press LLC, Boca Raton

Norkko J, Bonsdorff E, Norkko A (2000) Drifting algal mats as an alternative habitat for benthic invertebrates: species specific responses to a transient resource. J Exp Mar Biol Ecol 248:79-104

Ólafsson EB, Persson L-E (1986) Distribution, life cycle and demography in a brackish water population of the isopod Cyathura carinata (Kröyer) (Crustacea). Estuar Coast Shelf Sci 23:673-687

Raffaelli DG, Raven JA, Poole LJ (1998) Ecological impact of green macroalgal blooms. Oceanogr Mar Biol Ann Rev 36:97-125

Reise K (2002) Sediment mediated species interactions in coastal waters. J Sea Res 48:127-141

Strickland JDH, Parsons TR (1972) A practical handbook of seawater analysis (Bulletin 167, Second edition). Fisheries Research Board of Canada, Ottawa, pp 71-80

Taylor LR (1989) Objective and experiment in long-term research. In: Likens GE (eds) Long-term studies in ecology. Approaches and alternatives. Springer, Berlin Heidelberg New York, pp 20-70

Valiela I, McClelland J, Hauxwell J, Behr PJ, Hersh D, Foreman K (1997) Macroalgal blooms in shallow estuaries. Controls and ecophysiological and ecosystem consequences. Limnol Oceanogr 42:1105-1118

Verdelhos T, Neto JM, Marques JC, Pardal MA (2005) The effect of eutrophication abatement on the bivalve Scrobicularia plana. Estuar Coast Shelf Sci 63:261-268 